Vol. 3, No 1, Juni 2020

Hal 14-27

\title{
FUNGSI MANGROVE SEBAGAI BIOFILTER LIMBAH BUDIDAYA UDANG VANAME PADA TAMBAK INTENSIF SUPM NEGERI BONE
}

\author{
(Function of Mangrove As A Biofilter of Vaname Shrimp Culture Waste \\ In Intensive Pond SUPM Negeri Bone)
}

\author{
Suryo Wirawan Anton 1), Anton 2), Dewi Virgiastuti Jarir 2), \\ Fatmah ${ }^{3)}$, Harlina Usman ${ }^{4)}$, Ilmiah ${ }^{4)}$ \\ 1) Magister Pesisir dan Teknologi Kelautan, UMI Makassar \\ 2) Politeknik Kelautan dan Perikanan Bone \\ 3) Balai Riset Perikanan Budidaya Air Payau dan Penyuluhan Perikanan, Maros \\ 4) Program Studi Budidaya Perairan FPIK UMI Makassar \\ Korespondensi: suryoanton93@gmail.com
}

Diterima: tanggal 10 Januari 2020; Disetujui 10 Feberuari 2020

\section{ABSTRACT}

This research was conducted in Juli-September 2019 in the Intensive Bone Pond SUPM Negeri Bone, Bone Regency. This study aims to: (1) Describe the condition of the study site for pond intercropping patterns; (2) Knowing the type and density of mangroves at the study site; (3) Assessing the role of mangroves as biofilter for the pollution of vaname shrimp pond cultivation. The method used in data collection is done by direct measurement to the field for water quality at the location of the pond, the type and density of mangroves determined by using transects. The results showed that the pond intercropping pattern used in the Bone State SUPM Pond was a model of an open trench pond. The type of mangrove that dominates the research location is Rhizopora mucronata and for vegetation density each station was different where in the tree category station 1 had a vegetation density of 0.48 ind $/ \mathrm{m}^{2}$, station II was 0.87 ind $/ \mathrm{m}^{2}$, station III was 1.06 ind $/ \mathrm{m}^{2}$. For the stake category 1 station has a vegetation density of $0.24 \mathrm{ind} / \mathrm{m}^{2}$, station II is 0.08 ind $/ \mathrm{m}^{2}$, station III is 0.68 ind $/ \mathrm{m}^{2}$. For the seedling category station 1 has a vegetation density of 77 ind $/ \mathrm{m}^{2}$, station II is 32 ind $/ \mathrm{m}^{2}$, station III is $15 \mathrm{ind} / \mathrm{m}^{2}$. Mangroves in the vicinity of SUPM Bone Bone can play a role as biofilter for the pollution of vaname shrimp aquaculture results with measurements of water quality before and after passing through mangroves decreased

Keywords: Mangrove, cultivation waste, intensive pond, mangrove density

\begin{abstract}
ABSTRAK
Penelitian ini dilaksanakan pada bulan Juli-September 2019 bertempat di Tambak Intensif SUPM Negeri Bone, Kabupaten Bone. Penelitian ini bertujuan untuk : (1) Mendeskripsikan kondisi lokasi penelitian terhadap pola tumpang sari tambak; (2) Mengetahui jenis dan kerapatan mangrove di lokasi penelitian; (3) Mengkaji peranan mangrove sebagai biofilter pencemaran limbah budidaya tambak udang vaname. Metode yang digunakan dalam pengumpulan data dilakukan dengan pengukuran langsung ke lapangan untuk kualitas air di lokasi tambak, jenis dan kerapatan mangrove ditentukan dengan menggunakan transek. Hasil penelitian menunjukkan bahwa Pola tumpang sari tambak yang digunakan di Tambak SUPM Negeri Bone merupakan model empang parit terbuka. Jenis mangrove yang mendominasi lokasi penelitian yaitu Rhizopora mucronata dan untuk kerapatan vegetasi tiap-tiap stasiun berbeda dimana pada kategori pohon stasiun 1 memiliki kerapatan vegetasi $0,48 \mathrm{ind} / \mathrm{m}^{2}$, stasiun II yaitu $0,87 \mathrm{ind} / \mathrm{m}^{2}$, stasiun III yaitu $1,06 \mathrm{ind} / \mathrm{m}^{2}$. Untuk kategori pancang stasiun 1 memiliki kerapatan vegetasi $0,24 \mathrm{ind} / \mathrm{m}^{2}$, stasiun II yaitu $0,08 \mathrm{ind} / \mathrm{m}^{2}$, stasiun III yaitu $0,68 \mathrm{ind} / \mathrm{m}^{2}$. Untuk kategori semai stasiun 1 memiliki kerapatan vegetasi $77 \mathrm{ind} / \mathrm{m}^{2}$, stasiun II yaitu $32 \mathrm{ind} / \mathrm{m}^{2}$, stasiun III yaitu $15 \mathrm{ind} / \mathrm{m}^{2}$. Mangrove yang berada di sekitar Tambak SUPM Negeri Bone dapat berperan sebagai biofilter pencemaran hasil limbah budidaya udang vaname dengan hasil pengukuran kualitas air sebelum dan setelah melewati mangrove mengalami penurunan.
\end{abstract}

Kata kunci: Mangrove, limbah budidaya, tambak intensif, kerapatan mangrove 



\section{PENDAHULUAN}

Kegiatan Budidaya yang sampai sekarang masih sangat digemari dan digeluti oleh para pelaku usaha perikanan salah satunya adalah Budidaya Udang Vaname. Seiring dengan berjalannya waktu kegiatan budidaya udang ini semakin yang memenuhi hajat hidup orang berkembang di seluruh Indonesia, banyak sehingga perlu dilindungi agar khususnya Budidaya Udang secara dapat bermanfaat bagi hidup dan intensif. Menurut Rahayu (2013), kehidupan manusia serta makhluk berkembangnya penerapan teknologi hidup lainnya. Untuk menjaga dan ini karena permintaan jumlah konsumsi mencapai kualitas air sehingga dapat udang yang semakin meningkat dari dimanfaatkan secara berkelanjutan tahun ke tahun baik pasar dalam negeri maupun pasar luar negeri, sehingga menuntut pula produktifitas udang semakin meningkat selain itu Pelestarian kualitas air merupakan masyarakat pembudidaya udang telah upaya untuk memelihara fungsi air agar mempunyai prinsip bahwa budidaya kualitasnya tetap pada kondisi alamiah. udang mampu menjanjikan hasil yang Pengelolaan kualitas air dilakukan tinggi tetapi juga sebanding dengan dengan upaya pengendalian biaya dan resiko yang tinggi pula, pencemaran air, yaitu menggunakan sehingga bermunculan perorangan tanaman mangrove (Dewa, 2016) maupun kelompok yang membuka lahan untuk melakukan budidaya udang.

Dengan banyaknya usaha tekanan yang tinggi terhadap berbagai budidaya tambak secara intensif yang jenis polutan, baik yang berasal dari semakin berkembang di Indonesia, laut maupun yang berasal dari darat tentu saja menimbulkan berbagai yang dibawa oleh sungai yang macam permasalahan. Salah satu bermuara di laut. Salah satu biota 
perairan yang terkena dampak langsung Mangrove Sebagai Biofilter Limbah

dari pencemaran logam di perairan Budidaya Udang Vaname Pada
adalah tumbuhan mangrove. Mangrove Tambak Intensif, SUPM Negeri Bone,

dari pencemaran logam di perairan Budidaya Udang Vaname Pada
adalah tumbuhan mangrove. Mangrove Tambak Intensif, SUPM Negeri Bone, yang tumbuh di muara sungai Kabupaten Bone”.

merupakan tempat penampungan bagi limbah-limbah yang terbawa aliran

sungai. Mangrove memiliki kemampuan menyerap bahan-bahan organik dan non organik dari lingkungannya ke dalam tubuh melalui membran sel (Darpi, 2017).

Untuk mengetahui tanaman mangrove dapat berfungsi sebagai filter limbah budidaya udang, diperlukan pengujian parameter kualitas air, seperti menentukan kandungan ammonia, nitrit, nitrat, dan padatan tersuspensi total.

SUPM Negeri Bone merupakan salah satu sekolah sederajat SLTA di bawah naungan Badan Riset Sumber Daya Manusia Kelautan dan Perikanan, Kementerian Kelautan dan Perikanan yang memiliki tambak intensif yang dikenal dengan nama BUSMETIK (Budidaya Udang Skala Mini Empang Plastik) yang dikelilingi oleh tanaman mangrove. Namun informasi tentang peranan mangrove terhadap budidaya 24 hari begitupun dengan jarak udang vaname masih kurang. pengambilan sampel ketiga. Skema Berdasarkan uraian tersebut, maka pengambilan sampel disajikan pada diperlukan suatu penelitian Fungsi Gambar 1.

Penelitian ini dilakukan selama 2 (dua) bulan, yaitu pada bulan JuliSeptember 2019 bertempat di Tambak SUPM Negeri Bone, Kabupaten Bone, Sulawesi Selatan. Hasil sampel kemudian diuji di laboratorium BRPBAP3 Maros, Sulawesi Selatan.

Teknik pengambilan sampel dilakukan dengan melalui uji pendahuluan yang meliputi, observasi lapangan untuk mengetahui kondisi lapangan dan penentuan stasiun penelitian serta untuk memastikan jenis mangrove yang ada pada tambak yang akan digunakan dalam penelitian sebenarnya. Pada penelitian ini menggunakan 3 stasiun di setiap lokasi yaitu sebelum dan setelah melewati mangrove. Setiap stasiun terdapat 3 (tiga) kali ulangan dan kegiatan ini dilakukan sebanyak 3 (tiga) kali, dimana jarak watu antara pengambilan sampel pertama ke sampel kedua yaitu

\section{MATERI DAN METODE}




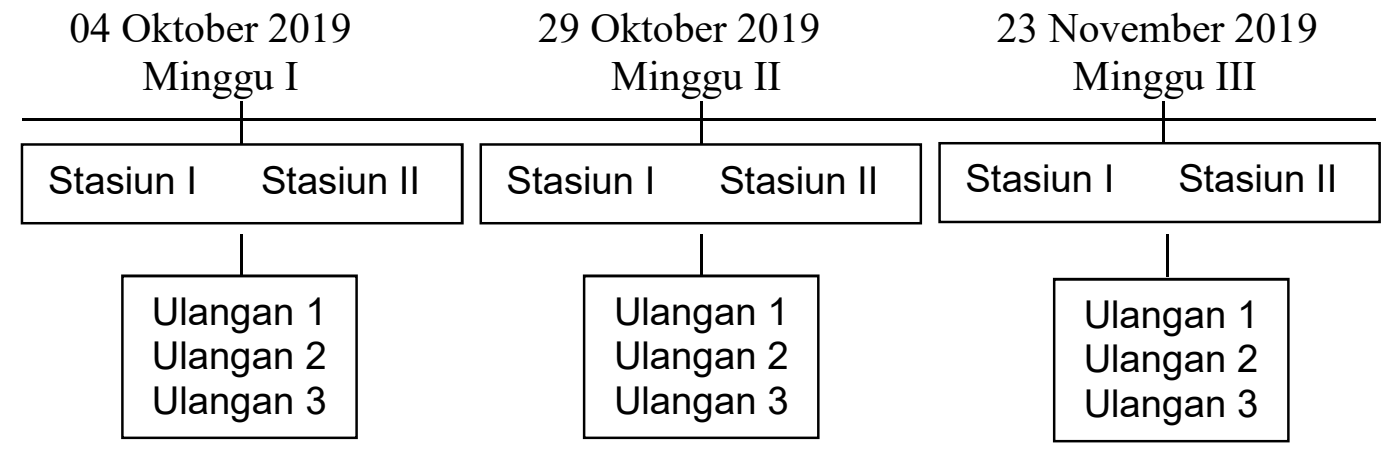

Gambar 1. Skema pengambilan sampel

Untuk penentuan kerapatan mangrove dilakukan transek 10x10m untuk kategori pohon, $5 \times 5 \mathrm{~m}$ untuk kategori pancang dan 1x1 m untuk kategori semai. Dimana setiap stasiun digunakan 3 (tiga) plot.

Pengambilan sampel air dilakukan dengan mengetahui pasang surut pada lokasi penelitian dan diambil pada saat kegiatan pergantian air. Untuk mengetahui nilai parameter kualitas air sebelum melewati mangrove dilakukan pengukuran di dalam tambak (pada saat surut) dan untuk mengetahui nilai parameter kualitas air setelah melewati mangrove dilakukan pada saat pasang.

Metode penelitian yang digunakan adalah metode deskriptif. Metode deskriptif adalah metode penelitian yang memberikan gambaran secara sistematis, faktual, akurat mengenai faktor - faktor dan sifat - sifat dari suatu daerah atau populasi (Suryabrata, 1992 dalam Budiasih, dkk, 2015). Untuk menentukan kerapatan mnagrove digunakan rumus sebagai berikut (Dharmawan dan Pramudji, 2014)

Kerapatan

$=\frac{S \text { individu jenis } i}{S \text { plot (luas semua kuadrat })} \times 10.000$ Alat dan bahan yang dapat menunjang dalam kegiatan ini. Adapun alat yang digunakan yaitu botol sampel, timbangan analititk, erlenmeyer, botol polietilen $250 \mathrm{ml}$, kertas saring, labu ukur, pipet volumetrik, pipet ukur, pipet tetes, desikator, spektrofotometrik, sedangkan alat untuk menentukan kerapatan mangrove yaitu meteran, tali rafia, spidol serta GPS. Bahan yang digunakan adalah sampel air tambak pemeliharaan udang dan ATK, serta kertas label. Untuk bahan kimia yang digunakan adalah larutan asam sulfat,larutan kalium antimonil tartrat, larutan amonium molibdat, larutan asam askorbat, air suling bebas nitrit, indikator fenolftalen 
sedangkan untuk bahan menentukan lokasi penenlitian jenis mangrove jenis mangrove yaitu buku identifikasi Rhizopora mucronata ini sangat mangrove.

\section{HASIL DAN PEMBAHASAN}

\section{Komposisi jenis mangrove}

Berdasarkan hasil pengamatan, ditemukan 2 (dua) jenis vegetasi pada stasiun I yaitu Rhizopora mucronata dan Sylocarpus geranatun. Komposisi vegetasi mangrove untuk tingkat pohon yang tertinggi pada lokasi penelitian adalah Rhizopora mucronata $99 \%$ dan jenis Sylocarpus geranatun $1 \%$. Rhizopora mucronata memiliki komposisi yang tertinggi karena karakteristik yang dimiliki lokasi penelitian ini cocok dengan karakteristik yang dimiliki oleh jenis Rhizopora mucronata (Noor, dkk, 2006).

Komposisi vegetasi mangrove kategori pancang hanya ditemukan 1 (satu) jenis mangrove yaitu Rhizopora mucronata. Sesuai dengan karakteristik mendominasi di lokasi penelitian. Komposisi vegetasi mangrove kategori semai terdapat 2 (dua) jenis mangrove yaitu Rhizopora mucronata dan Rhizopora apiculata, dimana kedua jenis mangrove ini sama-sama dari genus yang sama yaitu Rhizopora apiculata, akan tetapi dari spesies yang berbeda. Sehingga diperoleh komposisi mangrove jenis Rhizopora mucronata $69 \%$ dan untuk kompisisi jenis mangrove Rhizopora apiculata 31\%. Kedua jenis mangrove ini karena berasal dari satu genus maka karakteristik yang dibutuhkan untuk hidup mendukung dalam lokasi penelitian (Noor, dkk, 2006)

\section{Kerapatan Mangrove}

Hasil analsisi kondisi kerapatan mangrove di tambak Intensif SUPM Negeri Bone

Tabel 1. Kondisi kerapatan mangrove di tambak intensif SUPM Negeri Bone

\begin{tabular}{|c|c|c|c|c|c|c|}
\hline \multirow{2}{*}{ No } & \multicolumn{7}{|c|}{ Pohon } \\
\cline { 2 - 5 } & Stasiun & $\begin{array}{c}\text { Kategori } \\
\text { Kerapatan } \\
\text { Jenis }\end{array}$ & $\begin{array}{c}\text { Jenis } \\
\text { Mangrove }\end{array}$ & $\begin{array}{c}\text { Kerapatan } \\
\text { Jenis } \\
\left(\mathrm{ind} / \mathrm{m}^{2}\right)\end{array}$ & $\begin{array}{c}\text { Kerapatan } \\
\text { vegetasi } \\
\left(\mathrm{ind} / \mathrm{m}^{2}\right)\end{array}$ & $\begin{array}{c}\text { Kategori } \\
\text { kerapatan } \\
\text { mangrove } \\
\text { pada stasiun }\end{array}$ \\
\hline \multirow{2}{*}{1} & 1 & $\begin{array}{c}\text { Sangat } \\
\text { padat }\end{array}$ & $\begin{array}{c}\text { Rhizophora } \\
\text { mucronate }\end{array}$ & 0,47 & \multirow{2}{*}{0,48} & Sangat padat \\
\cline { 2 - 5 } & 2 & Jarang & $\begin{array}{c}\text { sylocarpus } \\
\text { geranatun }\end{array}$ & 0,01 & 0,87 & Sangat padat \\
\hline 2 & & Shizophora & 0,87 & 0, & & \\
\hline
\end{tabular}




\begin{tabular}{|c|c|c|c|c|c|c|}
\hline & & padat & mucronate & & & \\
\hline 3 & 3 & $\begin{array}{c}\text { Sangat } \\
\text { padat }\end{array}$ & $\begin{array}{l}\text { Rhizophora } \\
\text { mucronate }\end{array}$ & 1,06 & 1,06 & Sangat padat \\
\hline \multicolumn{7}{|c|}{ Pancang } \\
\hline 4 & 1 & $\begin{array}{l}\text { Sangat } \\
\text { padat }\end{array}$ & $\begin{array}{l}\text { Rhizophora } \\
\text { mucronata }\end{array}$ & 0,24 & 0,24 & Sangat padat \\
\hline 5 & 2 & Jarang & $\begin{array}{l}\text { Rhizophora } \\
\text { mucronata }\end{array}$ & 0,08 & 0,08 & Jarang \\
\hline 6 & 3 & $\begin{array}{l}\text { Sangat } \\
\text { padat }\end{array}$ & $\begin{array}{l}\text { Rhizophora } \\
\text { mucronata }\end{array}$ & 0,68 & 0,68 & Sangat padat \\
\hline \multicolumn{7}{|c|}{ Semai } \\
\hline \multirow{2}{*}{7} & \multirow{2}{*}{1} & $\begin{array}{l}\text { Sangat } \\
\text { padat }\end{array}$ & $\begin{array}{l}\text { Rhizophora } \\
\text { mucronata }\end{array}$ & 56 & \multirow{2}{*}{77} & \multirow{2}{*}{ Sangat padat } \\
\hline & & $\begin{array}{l}\text { Sangat } \\
\text { padat }\end{array}$ & $\begin{array}{l}\text { Rhizophora } \\
\text { apiculata }\end{array}$ & 21 & & \\
\hline \multirow{2}{*}{8} & \multirow{2}{*}{2} & $\begin{array}{c}\text { Sangat } \\
\text { padat }\end{array}$ & $\begin{array}{l}\text { Rhizophora } \\
\text { mucronata }\end{array}$ & 20 & \multirow{2}{*}{32} & \multirow{2}{*}{ Sangat padat } \\
\hline & & $\begin{array}{l}\text { Sangat } \\
\text { padat }\end{array}$ & $\begin{array}{l}\text { Rhizophora } \\
\text { apiculata }\end{array}$ & 12 & & \\
\hline \multirow{2}{*}{9} & \multirow{2}{*}{3} & $\begin{array}{c}\text { Sangat } \\
\text { padat }\end{array}$ & $\begin{array}{l}\text { Rhizophora } \\
\text { mucronata }\end{array}$ & 5 & \multirow{2}{*}{15} & \multirow{2}{*}{ Sangat padat } \\
\hline & & $\begin{array}{l}\text { Sangat } \\
\text { padat }\end{array}$ & $\begin{array}{l}\text { Rhizophora } \\
\text { apiculata }\end{array}$ & 10 & & \\
\hline
\end{tabular}

Berdasarkan tabel 1, dapat memiliki kerapatan jarang karena pada diketahui bahwa untuk kategori kelas daerah tersebut kemungkinan terjadi kerapatan sangat padat untuk kategori karena tumbuhan mangrove tersebut kerapatan jenis pohon, pancang dan kurang mampu beradaptasi dengan semai terdapat pada semua stasiun kondisi lingkungan yang ada. pengamatan dan kategori kelas Daerah tersebut didominasi oleh kerapatan jarang hanya terdapat pada mangrove karena daerah tersebut belum stasiun 2 dengan kategori pancang yaitu tersentuh pembangunan untuk pada jenis Rhizophora mucronata pemukiman, tambak, serta menjadi dengan kerapatan jenis $0,08 \mathrm{ind} / \mathrm{m}^{2}$. tempat yang dilindungi oleh Untuk kategori kerapatan sangat padat pemerintah. Selain itu pasokan air pada kebanyakan stasiun disebabkan tawar, dan salinitas air tanah adalah karena lingkungan tempat mangrove faktor yang paling berpengaruh tumbuh sangat sesuai dan sebanding terhadap pertumbuhan mangrove di dengan kemampuan mangrove untuk wilayah ini. Letaknya yang berada hidup. Sedangkan stasiun yang dekat dengan laut (air asin) juga turut 
mempengaruhi pertumbuhannya. dengan tingkat kerapatan 5 ind $/ \mathrm{m}^{2}$. Dengan adanya pengaruh dari air laut, Untuk kategori pohon dengan maka bila mangrove tidak mampu kerapatan minimum mangrove 0,32 beradaptasi dengan kondisi lingkungan ind $/ \mathrm{m}^{2}$ terdapat pada stasiun I, yang ada dapat mengakibatkan sedangkan kerapatan maksimum kemampuan tumbuhnya akan sedikit dengan tingkat kerapatan 1,06 ind $/ \mathrm{m}^{2}$ terhambat. terdapat pada stasiun III. Untuk Untuk jenis mangrove kategori pancang dengan kerapatan Rhizophora mucronata yang terdapat minimum mangrove 0,08 ind $/ \mathrm{m}^{2}$ pada semua stasiun ini di karenakan terdapat pada stasiun II, sedangkan jenis mangrove tersebut tumbuh pada kerapatan maksimum dengan tingkat habitat yang beragam di daerah pasang kerapatan $0,68 \mathrm{ind} / \mathrm{m}^{2}$ terdapat pada surut, lumpur, pasir dan batu serta stasiun III. Untuk kategori semai menghasilkan bunga dan buah dengan kerapatan minimum mangrove sepanjang tahun kemungkinan $5 \mathrm{ind} / \mathrm{m}^{2}$ terdapat pada stasiun III, diserbuki oleh angin. Walaupun sedangkan kerapatan maksimum demikian, dari beberapa stasiun dengan tingkat kerapatan 56 ind $/ \mathrm{m}^{2}$ terdapat tingkat kerapatan yang berbeda terdapat pada stasiun I.

dimana pada kategori pohon stasiun I Lebih lanjut, Supriharyono memiliki tingkat kerapatan $0,32 \mathrm{ind} / \mathrm{m}^{2}$, (2000) menyatakan bahwa frekuensi pada stasiun II dengan tingkat arus pasang berpengaruh pada kerapatan $0,87 \mathrm{ind} / \mathrm{m}^{2}$, pada stasiun III kepadatan vegetasi, salinitas air tanah dengan tingkat kerapatan $1,06 \mathrm{ind} / \mathrm{m}^{2}$. akan berpengaruh terhadap struktur Untuk kategori pancang pada stasiun I akar, suhu air, tinggi, dan waktu dengan tingkat kerapatan $0,24 \mathrm{ind} / \mathrm{m}^{2}$, genangan air akan sangat pada stasiun II dengan tingkat mempengaruhi kondisi salinitas tanah, kerapatan $0,08 \mathrm{ind} / \mathrm{m}^{2}$, pada stasiun III selanjutnya salinitas tanah akan sangat dengan tingkat kerapatan $0,68 \mathrm{ind} / \mathrm{m}^{2}$. menentukan kelangsungan hidup Untuk kategori semai pada stasiun I mangrove dan berpengaruh terhadap dengan tingkat kerapatan $56 \mathrm{ind} / \mathrm{m}^{2}$, pola sebaran (zonasi) mangrove. Hal ini pada stasiun II dengan tingkat berarti bahwa zonasi di hutan mangrove kerapatan $20 \mathrm{nd} / \mathrm{m}^{2}$, pada stasiun III tergantung pada keadaan tempat 
tumbuh spesifik yang berbeda dari satu stasiun berbeda dimana pada kategori tempat dengan tempat yang lainnya. pohon stasiun 1 memiliki kerapatan Daya adaptasi dari tiap spesies vegetasi $0,48 \mathrm{ind} / \mathrm{m}^{2}$, stasiun II yaitu tumbuhan mangrove terhadap keadaan $0,87 \mathrm{ind} / \mathrm{m}^{2}$, stasiun III yaitu 1,06 tempat tumbuh akan menenentukan ind $/ \mathrm{m}^{2}$. Untuk kategori pancang stasiun komposisi spesies yang menyusun 1 memiliki kerapatan vegetasi 0,24 suatu vegetasi mangrove.

Untuk jenis mangrove sylocarpus ind $/ \mathrm{m}^{2}$, stasiun II yaitu $0,08 \mathrm{ind} / \mathrm{m}^{2}$, stasiun III yaitu $0,68 \mathrm{ind} / \mathrm{m}^{2}$. Untuk geranatun dan Rhizophora apiculata kategori semai stasiun 1 memiliki hanya terdapat pada beberapa stasiun kerapatan vegetasi $77 \mathrm{ind} / \mathrm{m}^{2}$, stasiun II dan kategori jenis. Untuk jenis yaitu $32 \mathrm{ind} / \mathrm{m}^{2}$, stasiun III yaitu 15 mangrove sylocarpus geranatun hanya ind $/ \mathrm{m}^{2}$. Untuk kategori kerapatan terdapat pada stasiun 1 kategori pohon mangrove pada stasiun hanya pada dengan tingkat kerapatan $0,01 \mathrm{ind} / \mathrm{m}^{2}$, stasiun 2 kategori pancang yang sedangkan untuk jenis mangrove memiliki tingkat kategori jarang Rhizophora apiculata terdapat di semua sedangkan di smeua stasiun dan stasiun akan tetapi hanya terdapat pada kategori baik pohon, pancang dan kategori semai dengan tingkat semai memiliki kategori sangat padat. kerapatan Stasiun 1 yaitu $21 \mathrm{ind} / \mathrm{m}^{2}$, Hal ini disebabkan karena tumbuhan stasiun 2 yaitu $12 \mathrm{ind} / \mathrm{m}^{2}$, dan stasiun 3 mangrove disekitar tambak SUPM yaitu $10 \mathrm{ind} / \mathrm{m}^{2}$. Hal ini dapat terjadi Negeri Bone ini merupakan mangrove karena hanya sebagian kecil jenis ini yang tumbuh secara alami sehingga yang mampu beradaptasi dengan persebaran tingkat kerapatnnya tidak kondisi lingkungan yang ada. beraturan. Seperti yang ditunjukan pada Mengingat jenis substratnya berupa tabel diatas bahwa tingkat kerapatan lumpur berpasir dan tanah gambut jarang terjadi pada stasiun 2 jenis sehingga jenis ini memerlukan adaptasi pancang dengan jenis mangrove khusus, yaitu pada bagian Rhizophora mucronata padahal di perakarannya. Juga karena faktor regenerasi yang seringkali terbatas.

Dari tabel diatas juga diketahui bahwa kerapatan vegetasi tiap-tiap 

semua stasiun mulai dari kategori Amonia

pohon, pancang dan semai tergolong

Hasil pengukuran kadar sangat padat.

Parameter Kualitas Air ammonia di lokasi penelitian dapat dilihat pada Gambar 2

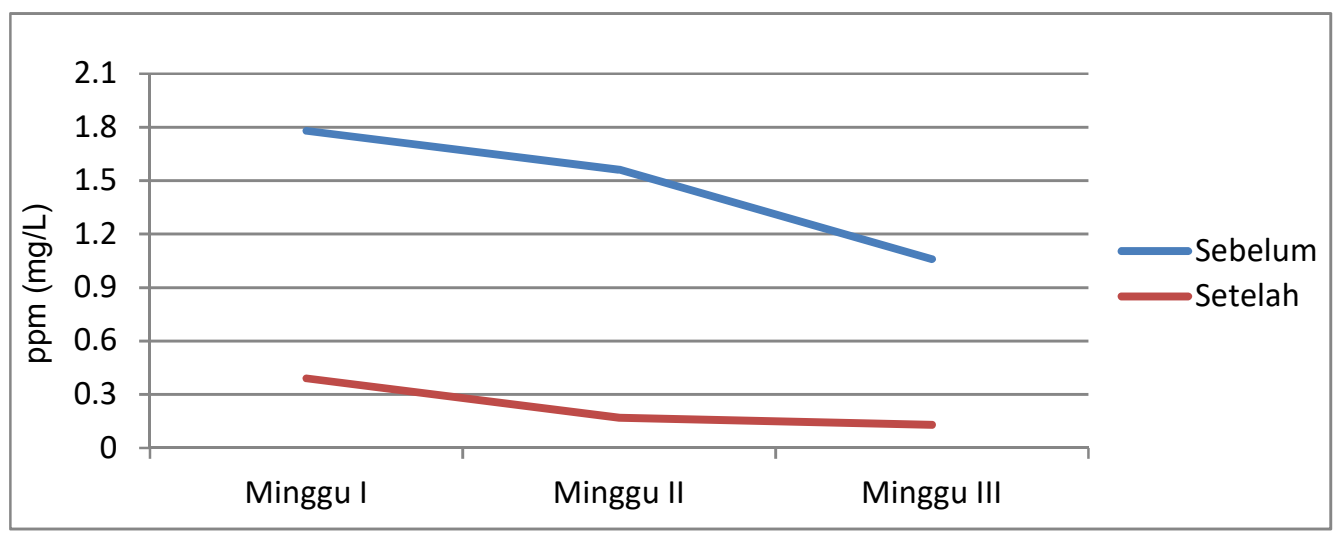

Gambar 2. Hasil pengukuran amonia sebelum dan setelah melewati mangrove

Hasil pengukuran kadar amonia pakan hanya tergantung pada pakan berdasarkan Gambar 2, menunjukan buatan dan diberikan secara intensif. bahwa dari minggu I, II sampai minggu Hal ini sesuai dengan pendapat III mengalami penurunan setelah Buwono (1993) bahwa pada budidaya melewati mangrove dimana pada intensif yang padat penebaran tinggi minggu I kadar amonia sebelum dan pemberian pakan secara intensif, melewati mangrove yaitu $1,78 \mathrm{mg} / 1$ dan keadaan tersebut dapat menimbulkan setelah melewati mangrove yaitu 0,39 penimbunan limbah kotoran dari sisa $\mathrm{mg} / \mathrm{l}$, pada minggu II dari nilai 1,56 pakan, bangkai udang atau jasad lain $\mathrm{mg} / \mathrm{l}$ menjadi $0,17 \mathrm{mg} / \mathrm{l}$, serta minggu yang terjadi sangat cepat dan III dari nilai 1,06 mg/l menjadi 0,13 jumlahnya sangat banyak di dasar mg/l. Hasil ini menunjukan bahwa telah tambak. Selain itu Soetomo (2002), terjadi penimbunan limbah kotoran menyatakan bahwa jumlah amonia di baik dari sisa pemberian pakan maupun dalam tambak akan bertambah sejalan jasad renik lainnya, selain itu nilai dengan aktifitas proses perombakan amonia yang tinggi juga disebabkan dan meningkatnya suhu air.

karena tambak BUSMETIK ini Hasil pengukuran kadar amonia memang merupakan tambak intensif yang diperoleh limbah budidaya udang yang dimana pada sistem pemberian menunjukkan nilai kadar amonia yang 

berbahaya dan dapat menimbulkan baik, mangrove bukan saja mampu pencemaran di lingkungan sekitar tumbuh di tanah dengan konsentrasi karena bersifat racun ketika dilakukan racun yang tinggi, tetapi mereka juga secara terus menerus. Hal ini sesuai mengumpulkan/mengakumulasi unsur dengan pendapat Soetomo (2002) tersebut di dalam batang dan daun bahwa kandungan amonia dalam air dengan jumlah yang mungkin lebih tidak boleh lebih dari $0,1 \mathrm{ppm}$ atau 1 tinggi dan mematikan bagi organisme $\mathrm{mg} / \mathrm{L}$. hidup lainnya.

Setelah melewati mangrove, Nitrit seperti yang ditunjukan pada Gambar 2

Kisaran kandungan nitrit yang bahwa hasil penurunan kadar amonia diperoleh dalam penelitian ini untuk yang terjadi, maka mangrove di sekitar kadar nitrit hasil limbah budidaya tambak mampu menurunkan kadar udang vaname adalah<0,0010 mg/L, amonia sebesar $0,93-1,39 \mathrm{mg} / \mathrm{l}$. Hal hasil kadar nitrit pada lokasi penelitian ini sesuai dengan pendapat Kr'bek, dkk setelah melewati mangrove tidak terjadi (2011) dalam penelitiannya perubahan yaitu $<0,0010 \mathrm{mg} / \mathrm{L}$ (Tabel menyampaikan, bahwa mangrove 1)

merupakan hyperaccumulators yang

Tabel 1. Hasil kadar nitrit sebelum dan setelah melewati mangrove

\begin{tabular}{|l|c|c|c|}
\hline \multirow{2}{*}{ Stasiun Penelitian } & \multicolumn{3}{|c|}{ Waktu } \\
\cline { 2 - 4 } & Minggu I & Minggu II & Minggu III \\
\hline Sebelum & $<0,0010$ & $<0,0010$ & $<0,0011$ \\
\hline Setelah & $<0,0010$ & $<0,0009$ & $<0,0009$ \\
\hline
\end{tabular}

Hasil kadar nitrit yang diperoleh keadaan stabil. Hal ini sesuai dengan sesuai dengan Tabel 1, menunjukkan pendapat Boyd (1982), konsentrasi bahwa masih layak untuk perairan. Hal nitrit lebih kecil daripada nitrat karena ini sesuai dengan baku mutu PP No. 82 nitrit bersifat stabil jika terdapat Tahun 2001 yaitu $0,06 \mathrm{mg} / \mathrm{L}$. Tidak oksigen.Nitrit merupakan bentuk adanya perubahan kadar nitrit sebelum peralihan antara amonia dan nitrat dan dan setelah melewati mangrove gas hidrogen melalui proses dimungkin karena tersedianya oksigen dinitrifikasi.

yang cukup di dalam ekosistem mangrove sehingga kondisi dalam 
Nitrat

Seperti yang dilihat pada Gambar

3 menunjukkan bawa kadar nitrat nit sebelum melewati mangrove berkisar antara $0,09-0,13 \mathrm{mg} / 1$ dan setelah melewati mangrove berkisar antara $0,09-0,31 \mathrm{mg} / \mathrm{l}$. Hasil pengukuran nitrat di lokasi penelitian dapat dilihat pada Gambar 3

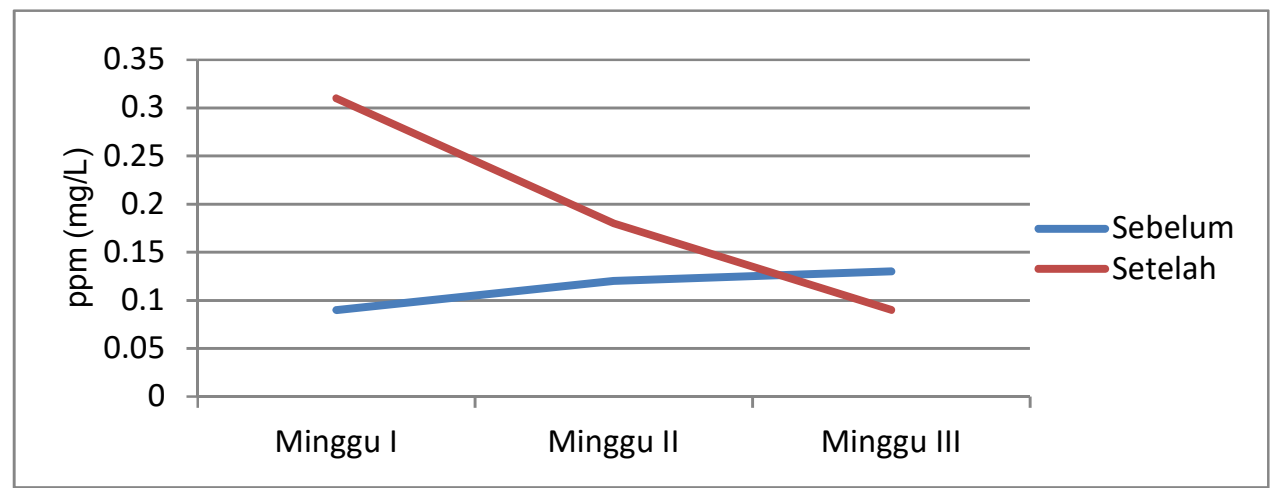

Gambar 3. Hasil pengukuran nitrat sebelum dan setelah melewati mangrove

Kadar nitrat sebelum dan setelah melewati mangrove masih dalam kondisi normal kecuali pada mingu I setelah melewati mangrove konsentrasi kadar nitrat melebihi batas normal sebagaimana yang dikemukakan oleh Effendi (2000) bahwa kadar nitrat yang melebihi $\quad 0,2 \quad \mathrm{mg} / \mathrm{L} \quad$ dapat mengakibatkan terjadinya eutrofikasi (pengayaan) perairan yang selanjutnya menstimulir pertumbuhan algae dan tumbuhan air secara pesat.

Jika hal ini terjadi maka akan dekomposer menjadi unsur hara seperti terjadi blooming dengan kata lain akan fosfat, nitrat dan sulfur. Akan tetapi terjadi pencemaran perairan yang kondisi ini berbanding terbalik dengan disebabkan oleh munculnya nutrient pernyataan Simon, dkk (2015) bahwa yang berlebihan kedalam ekosistem air. kadar nitrat di suatu ekosistem 
mangrove akan lebih rendah karena fungsi mangrove sebagai biofilter digunakan oleh fitoplankton dan pencemaran ini tidak serta merta bisa organisme lain yang berasosiasi di dikatakan tidak efektif. Karena ada dalamnya. Sedangkan kadar nitrat beberapa faktor alam yang dapat setelah melewati mangrove pada mempengaruhi kandungan kadar nitrat minggu III memperlihatkan kondisi yang ada.

sebaliknya yaitu mengalami penurunan hal ini dikarenakan waktu pengambilan sampel pada minggu III sudah memasuki musim hujan sehingga serasah daun mangrove tidak berpengaruh terhadap hasil konsentrasi nitrat.

Akan tetapi meskipun setelah melewati mangrove kadar nitrat pada minggu I dan minggu III lebih tinggi,

\section{TSS (Total Suspended Solid)}

Hasil pengukuran kandungan TSS sebelum dan setelah melewati mangrove seperti pada Gambar 4 menunjukkan bahwa kandungan TSS sebelum melewati mangrove berkisar antara $62-79 \mathrm{mg} / \mathrm{L}$ sedangkan setelah melewati mangrove berkisar antara 51$73 \mathrm{mg} / \mathrm{L}$.

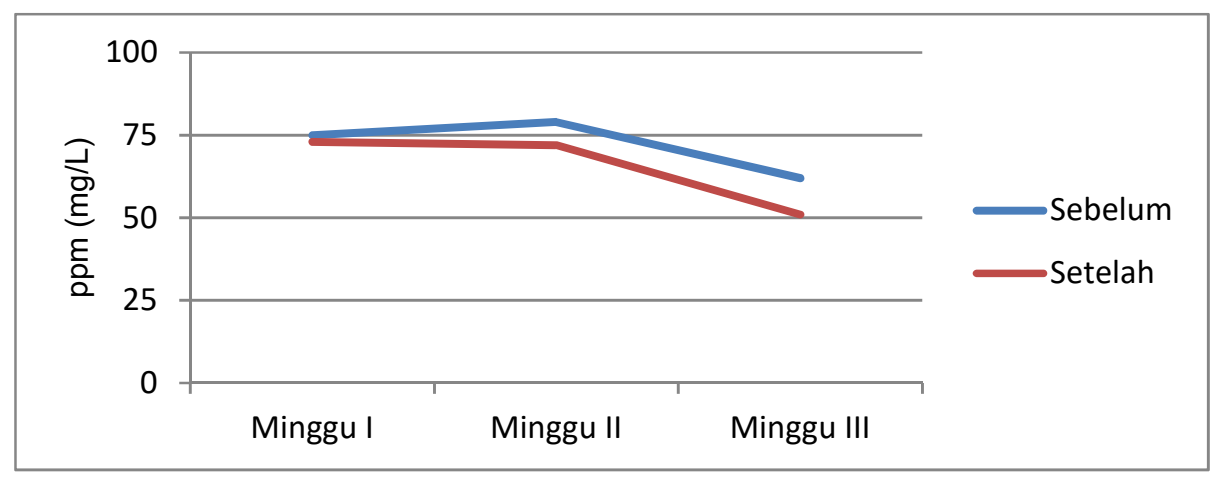

Gambar 4. Hasil pengukuran TSS sebelum dan setelah melewati mangrove

Seperti pada Gambar 4 dan untuk minggu III yaitu dari 62 menunjukkan bahwa dari minggu I, mg/L menjadi $51 \mathrm{mg} / \mathrm{L}$. Dari hasil minggu II dan minggu III mengalami pengukuran semua menunjukkan penurunan. Dimana pada minggu I bahwa kadar TSS sudah melewati penurunan nilai kadar TSS dari 75 ambang batas, dimana berdasarkan mg/L menjadi 73 mg/L, untuk minggu Baku Mutu Air Kelas II (PP RI No. 82 II yaitu dari $79 \mathrm{mg} / \mathrm{L}$ menjadi $72 \mathrm{mg} / \mathrm{L}$, 
Tahun 2001) bahwa untuk kadar TSS yaitu $50 \mathrm{mg} / \mathrm{L}$.

Dari hasil yang telah diperoleh berarti penurunan nilai TSS pada minggu I yaitu sebesar $2 \mathrm{mg} / \mathrm{L}$, untuk minggu II sebesar $7 \mathrm{mg} / \mathrm{L}$ dan untuk minggu III sebesar $11 \mathrm{mg} / \mathrm{L}$. Penurunan paling besar terjadi pada minggu III dan penurunan paling sedikit terjadi pada minggu I. Sehingga penurunan kadar nilai TSS pada penelitian ini setelah melewati mangrove berkisar antara 2$11 \mathrm{mg} / \mathrm{L}$. Perbedaan nilai kadar TSS setiap minggu karena dipengaruhi oleh tingkat kekeruhan, seperti yang dikemukakan oleh Downing (2008) bahwa keterkaitan nilai kekeruhan dan konsentrasi TSS di perairan sangat bervariasi.

\section{KESIMPULAN}

Berdasarkan hasil pembahasan
maka dapat ditarik beberapa
kesimpulan yaitu pola tumpang sari tambak yang digunakan di Tambak SUPM Negeri Bone merupakan model empang parit terbuka, jenis mangrove yang mendominasi lokasi penelitian yaitu Rhizopora mucronata dengan kategori kerapatan mangrove sangat padat danc. Mangrove yang berada di sekitar Tambak SUPM Negeri Bone dapat berperan sebagai biofilter pencemaran hasil limbah budidaya udang vaname dengan hasil pengukuran kualitas air sebelum dan setelah melewati mangrove mengalami penurunan.

\section{SARAN}

Sebaiknya dilakukan pengujian lebih lanjut tentang peranan mangrove khususnya dalam hal limbah budidaya udang vaname, karena sebagian besar para pembudidaya tidak menyediakan IPAL sebagai tempat untuk mengelola limbah sebelum dibuang ke perairan, sedangkan kualitas lingkungan perairan semakin menurun dan akan berdampak pada keberlanjutan kegiatan usaha budidaya udang itu sendiri.

\section{UCAPAN TERIMA KASIH}

Penulis mengucapkan terima kasih kepada Kepala Sekolah Usaha Perikanan Menengah (SUPM) Negeri Bone dan Laboratorium BRPBAP3 Maros, Sulawesi Selatan.

\section{DAFTAR PUSTAKA}

Boyd, C. E. 1982. Water Quality Management for Pond Fish Culture Development in Aquaculture and Fish Science, Vol. 9. Elsevier Scintific Pub. Comp.

Budiasih.R, Supriharyono dan Muskananfola, M.R. 2015. Analisis Kandungan Bahan Organik, Nitrat, Fosfat pada Sedimen di Kawasan Mangrove 
Jenis Rhidzophora dan Avicennia di Desa Timbulsloko, Demak. Jurnal Of Maquares. Management of Aquatic Resources. Volume 4. Nomor 3 Tahun 2015. Hal. 66-75. Budihastuti. 2013. Pengaruh Penerapan Wanamina Terhadap Kualitas Lingkungan Tambak dan Pertumbuhan Udang di Kota Semarang. Prosiding Seminar Nasional Pengelolaan Sumberdaya Alam dan Lingkungan 2013

Buwono, I.D,. 1993. Tambak Udang Windu Sistem Pengelolaan Intensif. Kanisius.

Dharmawan, W.E. dan Pramudji. 2014. Panduan Monitoring Status Ekosistem Mangrove. Pusat Penelitian Oseanografi LIPI. Coremap CITI LIPI. Jakarta

Darpi, H.A. 2017. Konsentrasi Logam Timbal $(\mathrm{Pb})$ di Sedimen dan Perakaran Mangrove pada Tingkat Kepadatan Mangrove yang Berbeda di Dusun Ampallas, Kabupaten Mamuju, Sulawesi Barat. Skripsi. Departemen Ilmu Kelautan. Fakultas Ilmu Kelautan dan Perikanan. Universitas Hasanuddin. Makassar.

Dewa, R. 2016. Penanganan Baku Mutu Kualitas Air Limbah Produksi Atc Dari Rumput Laut EucheumaCottonii.Ambon.Balai Riset dan Standardisasi Industri MajalhBiam.

Effendi, H. 2003. Telaah kualitas air. Kanisius. Yogyakarta

Keputusan Menteri Lingkungan Hidup No. 201 Tahun 2004 Tentang Kriteria Baku dan Pedoman Penentuan Kerusakan Mangrove

Kr'bek, B., Mihaljevic, M., Sracek, O., Kne'sl, I., Ettler, V. dan Nyambe, I. 2011. The Extent of Arsenic and of Metal Uptake by
Aboveground Tissues of Pteris vittata and Cyperus involucratus Growing in Copper- and CobaltRich Tailings of the Zambian Copperbelt. Arch Environ Contam Toxicol 61:228-242

Noor YR., Khazali, dan Suryadiputra. 2006. Panduan Pengenalan Mangrove di Indonesia. Ditjen PHKA dan Wetlands International. Bogor.

Peraturan Pemerintah No. 82. 2001. Tentang Pengelolaan Kualitas Air dan Pengendalian Pencemaran Air. Jakarta. Departemen Dalam Negeri.

Rahayu, H. 2013. Busmetik (Budidaya Udang Skala Mini Empang Plastik). STP Press. Jakarta Selatan

Supriharyono. 2000. Pelestarian dan Pengelolaan Sumber Daya Alam di Wilayah Pesisir Tropis. PT. Gramedia Pustaka Utama. Jakarta Soetomo, M. H. A. 2000. Teknik Budidaya Udang Windu. Sinar Baru Algensindo. Bandung. 